\title{
ARFRP1 wt Allele
}

National Cancer Institute

\section{Source}

National Cancer Institute. ARFRP1 wt Allele. NCI Thesaurus. Code C143138.

Human ARFRP1 wild-type allele is located in the vicinity of 20q13.33 and is approximately

$9 \mathrm{~kb}$ in length. This allele, which encodes ADP-ribosylation factor-related protein 1, is involved in GT Pase activity and trans-Golgi protein localization. 